\title{
The Effect of Parents Attention, Learning Discipline and Learning Motivation to Learning Outcomes of Students at the Student Financial Accounting Class
}

\author{
Listinawati Haditama ${ }^{1}$, Yunia Wardi' ${ }^{2}$ Syamwil $^{3}$ \\ ${ }^{123}$ Universitas Negeri Padang, Padang - Indonesia, ( listina_haditama@yahoo.com)
}

\begin{abstract}
The purpose of this research is to determine the influence of Parents Attention, Learning Discipline, and Learning Motivation to learning outcomes of students at the student Financial Accounting Class XI SMK Negeri in Business and Management Department of Padang. The population in this research were 221 students of class XI accounting. The sampling technique used is proportionate random sampling so that the sample of 142 students is obtained. Research instrument used in the form of questionnaire. Data analysis in this research using Path Analysis. The results of this research indicate that parents' attention has a significant effect and contribute to the discipline of learning. Parental attentions and discipline of learning have a significant effect on learning motivation. Attention parents, learning discipline, and learning motivation have a significant effect on the results of students' financial accounting learning class XI.
\end{abstract}

Keywords: parents attention, discipline, motivation

This is an open access article distributed under the Creative Commons 4.0 Attribution License, which permits unrestricted use, distribution, and reproduction in any medium, provided the original work is properly cited. (2018 by author and Faculty of education, Universitas Negeri Padang.

\section{Introduction}

Education as a process of human learning to become better, which serves humanize human and lasts throughout human life. Implementation of effective and efficient teaching and learning process aims to improve the quality of education, so that learning outcomes can be achieved more optimally. Learning outcomes are the abilities that a learner possesses after he / she receives his or her learning experience, which can be known through the value obtained by the learners within a certain period. Learning outcomes are always associated with the implementation of an activity or activity, because learning is a process, while learning results are the output of the learning process. Learning outcomes become a benchmark or criteria in achieving an educational goal. Sudjana (2013: 20) explains that "learning outcomes are a number of experiences that students have encompassed in the cognitive, affective, and psychomotor areas". Dimyati (2006: 200) argued that the learning outcome is the level of success achieved by students after following the learning where the success rate is marked by the scale of the value of numbers and letters. 
According to Dalyono (2007: 55) factors that affect learning outcomes are "1) internal factors include health, intelligence and talent, interest and motivation, and how to learn. 2) external factors include family, school, community, and the environment. Learning outcomes can be known by using one indicator that is the test. Cognitive tests are used to measure student learning outcomes relating to mastery of instructional materials in accordance with educational and teaching objectives. Based on observations obtained from SMKN Padang City Business and Management year 2016/2017 lesson learned that there are still many learners whose value is still below KKM (Criteria Completed Minimum)

Dalyono (2007: 235) reveals that "motivation serves to generate, underlie, direct the action of learning". Djamarah (2011: 148) "motivation that is as a driving force that transforms energy in a person into the form of real activity to achieve certain goals". In the learning process, motivation is necessary. A person who has no motivation in learning will not be possible to do learning activities.

High learning motivation can arise if each student has a high learning discipline as well. Discipline according to Tu'u (2004: 31) is "obedience and obedience that arises because of the awareness and encouragement from within each person". Meanwhile, according to Moenir (2010: 94) discipline is "a form of obedience to the rules, both written and unwritten, which has been established". Discipline integrates in everyone and becomes a part of one's life. Discipline really needs to be instilled in the students. Discipline is also a prerequisite for the formation of attitudes, behaviors and obedient disciplined life. So by having the attitude of discipline in learning learners become aware that with the discipline will be achieved optimal learning outcomes. According to Tu'u (2004: 38), the function of discipline is: 1) organize life together, 2) build personality, 3) train good personality, 4) coercion, 5) punishment, 6) create a conducive environment.

Family environment also affects the learning outcomes obtained by students. The family has a very important role in the education of children, because the family, especially the parents are the environment and people who are first recognized by children, so that basic education is the responsibility of parents. A child desperately needs the attention of his parents. Parental attention is an important factor to be considered in a child's education level.

The concern of parents is the deliberate, concentrated energy deliberation of parents based on a sense of full awareness, responsibility, and compassion for the achievement of satisfactory learning outcomes. The presence of supervision and direction given by parents will affect the students in following the learning activities in school.

According to Ahmadi (2007: 235), family environment is the beginning of the development of childhood personality is formed. Parents who apply strict rules at home will create children who have a disciplined attitude in children. Parental concern can be accomplished by accompanying children while studying at home, giving direction to children, controlling children's learning activities, giving good feedback to children. Children who feel received enough attention from their parents will lead to high learning semanga in children, so that learning results will be maximized.

From the above, the researcher intends to conduct research on the influence of parental attention, learning discipline, and motivation to learn the students' financial accounting learning outcomes Class XI SMK Negeri majoring in business and management of Padang city. 
Hypothesis of this research are:

1. Attention parents significantly influence the discipline of learning SMK Negeri students majoring in business and management of Padang city.

2. Parents attention and learning discipline have a significant effect on students' motivation to study SMK Negeri majoring in business and management of Padang city.

3. Attention parents, learning discipline, and motivation to learn significant effect on the results of learning financial accounting students SMK Negeri majoring in business and management of the city of Padang.

While from the relevant research results obtained as follows:

Imam Thoha (2016) on the influence of parental attention and discipline of learning on economic learning outcomes. The results showed that parents 'attention and discipline of learning have a great influence on students' economic learning outcomes.

Research conducted by Aleksandrs (2016) which shows that self-discipline and motivation is an indicator to improve learning outcomes with motede e-learning.

The findings suggest that parents 'attention, learning discipline, and learning motivation have a significant effect on students' financial accounting learning outcomes.

\section{Methods}

The kind of this research is a survey method. The population of this research is all class XI student of Student financial accounting Accounting majors management businessPadang city, as many as 221 people. The sampling technique is proportionate random sampling, in order to obtain the total sample of 142 people. The type and source of research data using primary data. The research instrument that uses a Likert scale questionnaire. Hypothesis analysis techniques using Path Analysis using SPSS 16.0, which at the same time to evaluate the model. The model used is the validity and reliability.

\section{Results and Discussion}

The results of the frequency distribution of the financial accounting student learning outcomes indicate the average value of the 142 midterm grade students accounting amounted to 78.83 . Students who accomplished the term is 98 people, while 44 others in the category of unfinished.

The results of the frequency distribution of parental included in the criteria fairly well, judging from the average score of 3.6 and TCR values of $71.7 \%$. That is a need to increase the attention of parents to improve student learning outcomes.

The results of the frequency distribution of the discipline of learning into the category of poor, visible from the average score of 3.1 with $61.4 \%$ TCR. This means that students do not have a good study discipline. Should the effort to improve student learning discipline, so that the learning outcomes will be obtained greatly.

As for the motivation to learn quite well belong to the category, with an average score of 3.7 and a TCR of $73.7 \%$. This means that student motivation is good enough, but that still needs to be improved in order to learn the results obtained are also maximized.

Normality test for each variable can be seen in the table below: 
Table 2. Normality Test One-Sample Kolmogorov-Smirnov Test

$\begin{array}{llllll} & & \text { PHO } & \text { DB } & \text { MB } & \text { Y } \\ \mathrm{N} & & 142 & 142 & 142 & 142 \\ \text { normal Parametersa } & \text { mean } & 77.04 & 62.89 & 62.63 & 78.83 \\ & \text { Std. deviation } & 11662 & 10133 & 8,066 & 16016 \\ \text { Most Extreme Differences } & \text { Absolute } & .073 & .100 & .086 & .106 \\ & \text { positive } & .052 & .054 & .086 & .106 \\ & \text { negative } & -.073 & -.100 & -.045 & -.100 \\ \text { Kolmogorov-Smirnov Z } & & .873 & 1,192 & 1,022 & 1,257 \\ \text { Asymp. Sig. (2-tailed) } & & .430 & .116 & .247 & .085 \\ & & & & \\ \text { a. Test distribution is Normal. } & & & & & \\ \end{array}$
Source: Primary Data Processed in 2017

The results obtained value of the Kolmogorov Smirnov> 0.05, ie 0,085 in Y; 0.430 for the variable $\mathrm{X} 1 ; 0.116$ to $\mathrm{X} 2 ; 0.247$ for $\mathrm{X} 3$. Thus the data are normally distributed.

Table 3. Test of Homogeneity Test of homogeneity of Variances

\begin{tabular}{lrrrr} 
& Levene Statistic & DF1 & DF2 & Sig. \\
Parents attention & 1,466 & 11 & 130 & .152 \\
discipline Learning & 1,282 & 7 & 133 & .264 \\
Motivation to learn & .677 & 7 & 133 & .691 \\
\hline
\end{tabular}

Source: Primary Data Processed, 2017

For parental variables (X1) was obtained at 0.152 with significant value greater than 0.05 then the data expressed concern of parents is homogeneous, to learn discipline variables (X2) obtained for o, 264 with significant value greater than 0.05 and for learning motivation variable (X3) obtained at 0.691 with significant value greater than 0.05 , it means that this variable has a homogeneous variance. Thus, after the normal data distribution and homogeneous, it can proceed to the next analysis, the path analysis.

\section{Path analysis}

1. The influence of parental variables $(X 1)$ to learn discipline variables $(X 2)$ based on the processed SPSS output, it can be seen in Table 4 below:

Table 4. Parents attention coefficient of the Discipline Study

\begin{tabular}{lccc}
\hline \multicolumn{1}{c}{ variables } & $\begin{array}{c}\text { coefficient } \\
\text { Line }\end{array}$ & t Count & Sig. \\
Parents attention $(\mathbf{X 1})$ & 0914 & 26718 & 0000 \\
R Square $=\mathbf{0 . 0 9 7}$ & & & \\
\hline
\end{tabular}

Source: data processed by SPSS version 16.00 for Windows, 2017 
From the table above variable coefficient of parental lines (X1) to the discipline of learning (X2) as follows:

Values X1 path coefficient of the X2 (Px1x2) of 0.914 with $t=26.718$, meaning that a significant path coefficient.

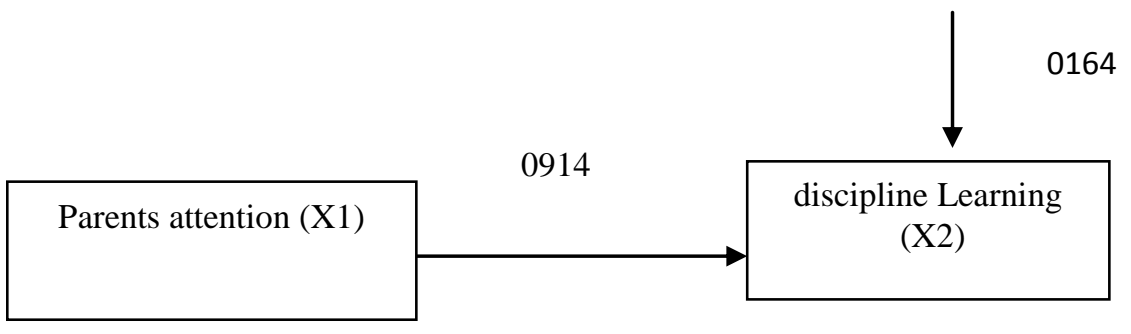

Figure 1. Sub Structure 1

Based on the above sub-structure, we can make the following equation:

$$
\begin{aligned}
& X 2=\varrho x 2 \times 1 X 1+\varepsilon \\
& X 2=0,914 X 1+0,405 \varepsilon 1
\end{aligned}
$$

2. The influence of parental variables (X1) and variable learning discipline (X2) on motivation to learn (X3) based on the processed SPSS output, it can be seen in table 4.8 below:

Table 5. Coefficient Line Parents attention and Discipline Learning Motivation Study

\begin{tabular}{lccccc}
\hline \multicolumn{1}{c}{ variables } & $\begin{array}{c}\text { coefficien } \\
\mathbf{t} \text { Line }\end{array}$ & $\mathbf{t}$ Count & Sig. & F Count & Sig. \\
\hline Parents attention (X1) & 0296 & 2,053 & 0000 & 77728 & 0000 \\
Learning discipline & 0446 & 3102 & 0000 & & \\
$\begin{array}{l}\text { X2) } \\
\text { R Square = 0528 }\end{array}$ & & & & & \\
\hline
\end{tabular}

Source: data processed by SPSS version 16.00 for Windows, 2017

Px3x1 $=0.296, t=2,053$ at sig. $0.000>0.05$, which means that the path coefficient was significant. Px3 $\times 2=0.446, t=3.102$ at sig. $0.000>0.05$, which means that the path coefficient was significant So it can be made a sub picture structure as follows:

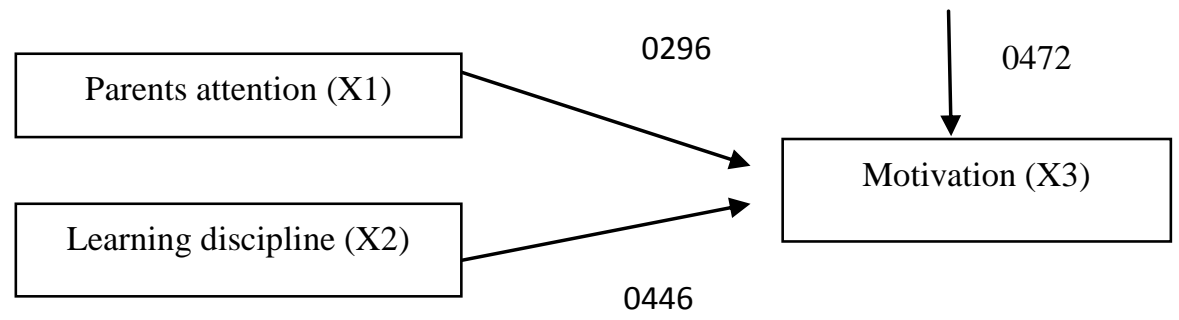

Figure 2. Structure Sub 2

Based on the above sub-structure, we can make the following equation:

$$
\begin{aligned}
& \mathrm{X}_{3}=\mathrm{P} \times 3 \times 1_{3} \mathrm{X}_{1}+\mathrm{P} \times 3 \times 2_{2} \mathrm{X}_{2}+\mathrm{PX} \varepsilon_{1} \\
& \mathrm{X}_{3}=0.296 \mathrm{X}_{1}+0.446 \mathrm{X}_{2}+0.472 \varepsilon_{1}
\end{aligned}
$$

3. The influence of parental variables (X1), variable learning discipline (X2), learning motivation variable (X3) on learning outcomes $(\mathrm{Y})$ based on the processed output, it can be seen in Table 4.9 below: 
Table 6. Coefficient Line Parents attention (X1), Discipline Learning (X2), and Motivation (X3) on Learning Outcomes (Y)

\begin{tabular}{lccccc}
\hline \multicolumn{1}{c}{ Variables } & $\begin{array}{c}\text { coefficient } \\
\text { Line }\end{array}$ & t Count & Sig. & F Count & Sig. \\
Parents attention (X1) & 0671 & 10958 & 0000 & 513.17 & 0000 \\
Learning discipline (X2) & 0250 & 4013 & 0000 & & \\
Motivation (X3) & 0072 & 2,016 & 0046 & & \\
R Square = 0178 & & & & & \\
\hline
\end{tabular}

Source: data processed by SPSS version 16.00 for Windows, 2017

The influence of parental (X1) on learning outcomes (Y), it is known that Pyx1 =0671, t $=10958$ in sig. $0.000>0.05$, which means that the path coefficient was significant.

Effect of learning discipline (X2) on learning outcomes (Y), it is known that Pyx2 $=0.250, t=4013$ on the sig. $0.000>0.05$, which means that the path coefficient was significant.

Effect of learning motivation (X3) on learning outcomes $(Y)$, it is known that Pyx3 $=0.072, t=2.016$ at sig. 0.046>0.05, which means that the path coefficient was significant.

From the results of data processing can be formulated and track structure variables influence the causes (exogenous) to the result variable (endogenous variable) in the following figure:

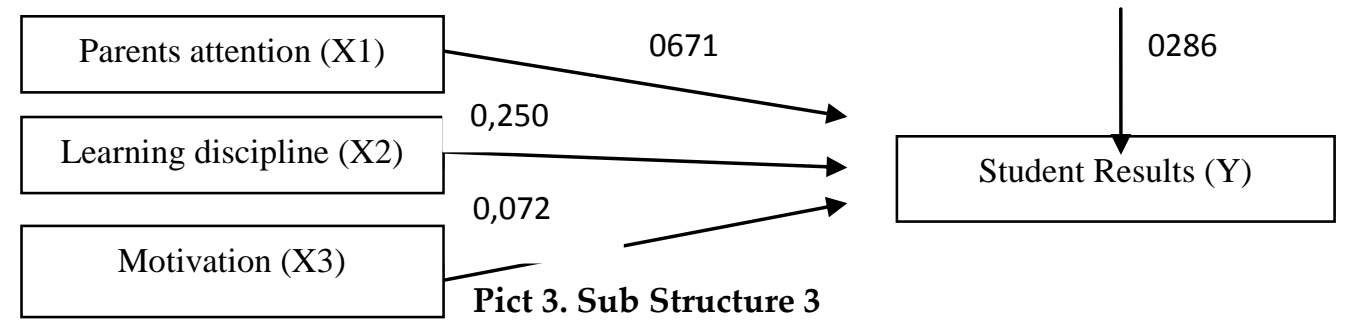

Based on the above sub-structures can be made structure following equation:

$$
\begin{aligned}
& Y=P Y X 1 P Y X 2 X 1+X 2+X 3+P Y P Y X 3 \varepsilon 2 \\
& X 1+Y=0.671+0.2860,250 X 2+0,072 X 3 \varepsilon 2
\end{aligned}
$$

From the results of data processing can be formulated and track structure variables influence the causes (exogenous) to the result variable (endogenous variable) in the following figure:

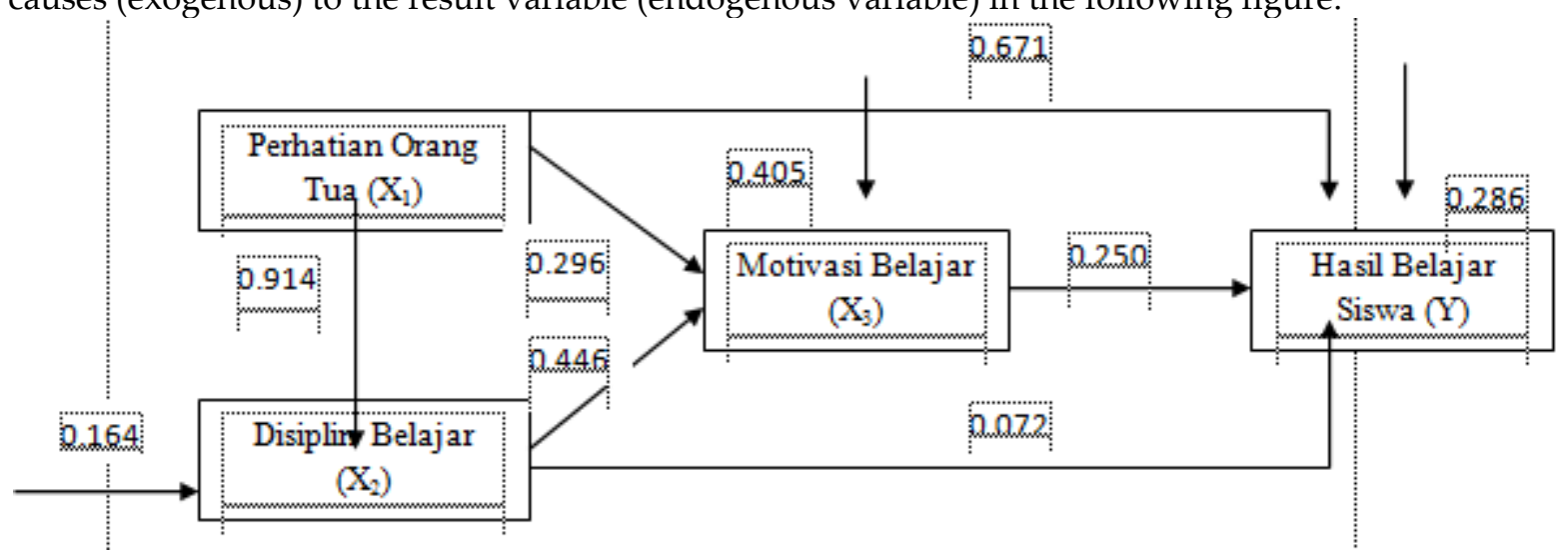

Pict 4. End of Line Variable Structure Research

\section{Discussion}

1. Effect of Parents attention To Discipline Learning at Student financial accounting class. 
Testing this hypothesis indicates that the concern of parents significantly influence the discipline learned in class XI student of Accounting Student financial accounting state 2, 3 and 4 Padang city. This means that the higher the attention given by the parents, it will increase student learning discipline. Vice versa, the lower the attention given by parents, then decreasing discipline of student learning. This is because the parents as caregivers and mentors in the family. Through the guidance and direction provided by the parents affect the spirit of the child to learn, in order to produce satisfactory results. In addition, basic education is the responsibility of parents, as families especially parents is the first environment that is known by the child.

In imposing discipline on students in school, can not be separated from the problem of discipline in the family. Compliance students in implementing the school rules will support the creation of effective teaching and learning process, and useful to obtain optimal learning results. The results of this analysis in accordance with the results of research conducted by Wahyu (2012) that concern parental influence on children in learning discipline and abide by discipline in schools.

So it can be concluded that the discipline of children will be formed of attention from their parents at home. Some things that can be conducted in an effort to give good attention to children is to give good treatment to children, such as by always advise children to pay attention when the teacher explains the subject matter, provide learning facilities at home, assisting children to learn at home, control the development and progress children's learning. The existence of a good push from parents, through feedback from parents to children, and parents should have enough time for the children, so children do not hesitate to discuss with parents. Therefore essential for the parents give enough attention to the child, so as to form a high learning discipline in children which in turn would improve learning outcomes to be obtained.

\section{Effect of Parents attention and Discipline Study to Learning Motivation at Student financial} accounting class

Based on hypothesis testing, it is known that parental supervision and discipline of study significantly influence student motivation Student financial accounting 2,3 and 4 of Padang.

The attention of parents to children and discipline of higher learning, the higher the students' motivation to learn both at school and at home. Conversely, if the attention given by parents is very low and the discipline learned too low, then it will be very low learning motivation. Students who have a strong discipline of study will be followed by the onset of motivation to learn. Where is the motivation to learn is a psychological condition that encourages students to learn, study results obtained will also increase. While the discipline of study itself will arise with parental supervision of children's learning activities at home.

Good attention received by children at home will lead to encouragement or motivation to learn are good also in children. Parents as educators should give priority to the interests and needs of children. These needs include the need for education and the need for moral support, as attention on the tasks of the school, the difficulties experienced by students while studying at school, and assist when children learn at home. As revealed Sardiman (2004: 102) that the motivation is always related to the issue of needs, such as the need to please others, the need to achieve results, and the need to overcome the difficulties.

The results also showed that the discipline of learning significantly influence the motivation to learn. This means that if the discipline of learning is higher, it will be better the motivation to learn owned by students. Conversely, the lower the learning discipline which is owned by the students, the lower the learning motivation. Discipline is necessary instilled in learners. In line with the opinions Hidayatullah (2010:5) that the enforcement of discipline among other things can be done in several ways such as increased motivation, education and training, implementation of reward and punishment, implementing rules. So as to have discipline in learning, students become aware that the discipline will achieve optimal learning results. 
With the discipline of learning in students, it can lead to impulse, the desire, and the will to succeed, having motivated to obtain maximum results, and have hopes andideals. In learning activities, motivation is very important supporting component for the smooth process of teaching and learning. Aside from being a mover of energy, motivation can also be used as a steering in any learning activities undertaken by students. So we can conclude that the discipline of learning does not directly affect student learning outcomes. That is a good learning outcomes are influenced by a high motivation to learn as a result of the high discipline of student learning. As disclosed Aleksandrs (2016: 257) two things to achieve success, namely the self-discipline and motivation.

3. Effect of Parents attention, Discipline Learning and Motivation Learning of the Financial Accounting Learning Outcomes at Student financial accounting class

Based on the test results of path analysis showed that the attention of parents directly affect student learning outcomes, with a value of $45.02 \%$. While indirectly affect parents' attention on learning outcomes through learning discipline of $4.42 \%$ and with the motivation to learn at $4.97 \%$. The value of the amount is known that, indirectly, greater parents attention influence through motivation to learn when compared to the discipline of learning.

The test results of the discipline of learning path analysis shows that directly affect learning outcomes with a value of $0.52 \%$ and indirectly through learning motivation of $0.80 \%$. It shows that the discipline of learning does not directly affect student learning outcomes when compared with immediate effect. So we can conclude that parental supervision and discipline of learning higher indirect influence on learning outcomes. This means that the motivation to learn as an intermediary that affects between parental supervision and discipline of learning on learning outcomes.

While the results of the path analysis influence the motivation to learn learn firsthand of $6.25 \%$. The results of this research was supported by the results of previous studies conducted by Chao Lee (2010) showed that student motivation have a significant effect on learning achievement. Its influence is a positive influence, meaning that the higher the students' motivation then it will be better the learning results obtained by the students. In line with the opinions Dalyono (2007: 235), which states that "the motivation to work cause, underlying, directing act of learning".

As the intermediate variables of learning motivation linking parental supervision and discipline of learning on learning outcomes. Learning motivation also plays an important role in the learning process. Students who have a high motivation to learn to be happy in learning activities, seen from his efforts to achieve a high score. With the motivation to learn also will raise the spirit of learning and a sense of fun to the subject. This is in line with the opinions Dalyono (2007: 235), which states that the function raises motivation, underlying, directing act of learning ".

Parents attention as an important role in causing the child's motivation to learn. Things that can be done in them by providing good treatment of the children, encourage children to excel, providing feedback on learning outcomes obtained by the child, and have the time to actively interact with the child. Thus the child feel cared well, so they will be motivated in learning.

In addition, parents should establish a good relationship with the child. This can be done by providing care that is full of love, giving direction to the child, and always build a harmonious relationship in the family, that will create a cozy home atmosphere for children, which in turn will encourage children to be more enthusiasm in learning. As stated Slameto $(2010 ; 62)$ that "a good relationship is a relationship of understanding and compassion, along with guidance, direction, and if necessary penalties to the success of children's learning".

The right attention is given by parents in children's learning activities will lead to the spirit of learning, so children are motivated to learn better. With a high learning motivation certainly learning results obtained are also getting better.

The discipline of learning to the learning outcomes are positive, that is to say with a high learning discipline directly or indirectly able to improve student learning outcomes. Indirectly 
discipline of learning through learning motivation mempenga Ruhi learning outcomes. Discipline is prerequisite for the formation of attitudes, behavior and adhere to a disciplined life. The discipline of learning that is formed in the student would pose a high motivation to learn. Students who have studied high discipline in him realized with a high learning motivation will facilitate the smooth running of the learning process. This is because the presence of discipline will prevent students from feeling lazy learning.

Students with learning discipline and a high learning motivation will likely be able to obtain a good learning outcomes. They will earnestly and concentrate in following classroom learning, students will come to school on time and always obey school rules, and if they are at home, students will learn regular and systematic. Therefore to get a good learning outcomes required a high learning motivation in students. High motivation to learn will be formed from the discipline of learning in students formed of attention given by parents in the home.

So the three variables of the most dominant influence on learning outcomes is attention from their parents. Because parents are the first and primary educators for their children, so parents have a huge role in children's education. Parents attention in educating children in the family environment is important, because the family is the best place to start an education. Tutorial parents about the importance of learning and guidance from parents to children will be able encourage a child to study harder, so the child will be easier to achieve optimal learning.

As expected for parents in order to further improve attention to children, this is necessary because the family is the first environment for a child. The family has an important role on teaching and child protection began birth to adolescence. In line with the opinions Slameto (2010: 60) that the way parents educate their children learn their greatest effect. So the success of student learning is strongly influenced by parenting applied to each student's parents. The formation of the discipline also came from the family. With the high discipline of study that will increase the motivation to learn is also high on students, so that will help to achieve maximum learning results.

\section{Conclusions}

Parents attention have a significant effect and contribute to the discipline of learning in students. Parental supervision and discipline of study have sifnifikan effect on student motivation. Parents attention, learning discipline, and motivation to learn a significant effect on learning outcomes either directly or indirectly. This shows that the better the attention given to the child's parents, the higher discipline of learning on students, as well as increasing student motivation then it will increase also results obtained by the student's learning. This is because the parents give sufficient attention to children, will foster self-discipline in children that lead to high motivation to learn and in turn will also improve student learning outcomes. So to be able to maximize student learning, parents need to increase attention to children, the formation of good study discipline in children, and to improve student learning motivation.

\section{References}

Aleksandrs Gorbunovs et al. Self-discipline As A Key Indicator to Improve Learning Outcomes in Learning Environment. Procedia - Social and Behavioral Sciences 231 (2016) 256-262

Amri, Sofan. (2013). Belajar dan Pembelajaran. Bandung: Alfabeta

Chaoo Lee, I. The Effect of Learning Motivation, Total Quality Teaching and Peer-Assisted Learning on Study Achievement: Empirical Analysis From Vocational Universities or Colleges' students in Taiwan. The Journal of Human Resource and Adult Learning Vol. 6. Num. 2, December 2010

Dimyati dan Mujiono. (2006). Belajar dan Pembelajaran. Jakarta: Rineka Cipta 
Dalyono, M. (2005). Psikologi Pendidikan, Komponen MKDK. Jakarta: Rineka Cipta Djamarah, Syaiful Bahri. (2011). Psikologi Belajar. Jakarta: Rineka Cipta

Hamalik, Oemar. (2013). Psikologi Belajar dan Mengajar. Bandung: PT. sinar Baru Algesindo

Hidayatullah, M. Furqon. (2010). Guru sejati: Membangun Insan Berkarakter Kuat dan Cerdas. Surakarta:

Yuma Pustaka

Moenir. (2010). Masalah-masalah Dalam Belajar. Yogyakarta: Pustaka Belajar

Nashori, Faud. (2005). Profil Orang Tua Anak-anak Berprestasi. Yogyakarta: Insania Cita Press

Sardiman, A.M. (2005). Interaksi dan motivasi Belajar Mengajar. Jakarta: Gravindo

Slameto. (2010). Belajar dan Faktor-faktor yang Mempengaruhi. Jakarta: Rineka Cipta

Soedijarto. (2003). Menuju Pendidikan Nasional yang Relevan dan Bermutu. Jakarta: Balai Pustaka

Sudjana, Nana. (2005). Penilaian Hasil Proses Belajar Mengajar. Bandung: PT. Remaja Rosdakarya

Sugihartono, dkk. (2013). Psikologi Pendidikan. Yogyakarta: UNY press

Tu'u. Tulus. 2004. Peran Disiplin pada Perilaku dan Prestasi Siswa. Jakarta: Gramedia

Wahyuni, Tri. (2012). Pengaruh Perhatian Orang Tua Terhadap Kedisiplinan Belajar Siswa di Sekolah Menengah Atas Negeri 12 Pekanbaru. Unduh online: repository.uinsuska.ac.id/10335/1/2012 2012921.pdf

Walgito, Bimo. (2005). Pengantar Psikologi Umum. Yogyakarta. Andi Offset 